\title{
EVALUASI PELAKSANAAN SISTEM RUJUKAN RAWAT JALAN NON- SPESIALISTIK BAGI PESERTA BPJS DI PUSKESMAS RAMBAH HILIR I KABUPATEN ROKAN HULU
}

\author{
Jihan Natassa ${ }^{1}$, Ummil Munawaroh ${ }^{2}$ \\ ${ }^{1,2}$ Program Studi Kesehatan Masyarakat STIKes Hang Tuah Pekanbaru
}

\begin{abstract}
Referral health is changing authority and responsibilities in reciprocal, both horizontal and vertical synchronization and structural and functional on the disease or problem. Based on data obtained from Health Sosial Security Organizer that the number of non-specialist outpatient referrals for sosial Security administrator participants in the Public Health Center Reaching Downstream I falls into the unsafe zone. This is because the number of referrals exceeds the predetermined target, which is 5.95\% while the achievement target is 5\%. This will affect the performance and service of the Puskesmas itself. The purpose of this study was to find out how the evaluation of the implementation of the Sosial Security Administrator program, especially in the non-specialist outpatient referral system for BPJS participants in the Public Health Center of Rambah Hilir I in Rokan Hulu Regency in 2018. The results of the study found that the availability of human resources is still lacking and not evenly distributed, the facilities and infrastructure are still incomplete, medicines are still not available, the outpatient referral is in accordance with the referral flow but there are still many references from the patient's own request. Follow-up has been done by the Public Health Center in the form of socialization to across sectors and communities. The conclusion of this study is that the availability of human resources, infrastructure and medicines at the Public Health Center is downstream I not in accordance with Minister of Health Regulation Number 75 of 2014 concerning Public Health Center, there are still many that need to be equipped and provided at Public Health Center of Rambah Hilir I. Regarding the implementation of outpatient referral systems for BPJS participants at the Public Health Center of Rambah Hilir I are in accordance with the set path, but because of the many referrals originating from the patient's own request resulting in a high number of referrals at the Public Health Center of Rambah Hilir I.
\end{abstract}

Keywords: Evaluation, Human Resources, Facilities and infrastructure, drugs, reference

\section{PENDAHULUAN}

Fasilitas kesehatan adalah fasilitas pelayanan kesehatan yang digunakan untuk menyelenggarakan upaya pelayanan kesehatan perorangan, baik promotif, preventif, kuratif maupun rehabilitatif yang dilakukan oleh Pemerintah, Pemerintah Daerah ataupun masyarakat. Sedangkan pelayanan kesehatan tingkat pertama adalah pelayanan kesehatan perorangan yang bersifat non spesialistik (primer) meliputi rawat jalan maupun rawat inap, seperti Puskesmas atau yang setara, Praktek Dokter, Praktek Dokter Gigi, Klinik Pratama atau yang setara termasuk fasilitas kesehatan tingkat pertama milik TNI/ POLRI dan Rumah Sakit Kelas D Pratama atau yang setara.
Rujukan kesehatan adalah pelimpahan wewenang dan tanggungjawab secara timbal balik, baik horizontal dan vertical maupun structural dan fungsional terhadap kasus penyakit atau permasalahan. Rujukan kesehatan berkaitan dengan upaya pencegahan dan peningkatan kesehatan (sarana, teknologi dan operasional) (Kemenkes, 2012).

Rujukan vertical merupakan rujukan antar pelayanan kesehatan yang berbeda tingkatan dapat dilakukan dari tingkatan pelayanan yang lebih rendah ke pelayanan yang lebih tinggi atau sebaliknya. Sedangkan rujukan horizontal adalah ujukan antar pelayanan kesehatan dalam satu tingkatan, dilakukan apabila perujuk tidak dapat memberikan pelayanan kesehatan sesuai 
dengan kebutuhan pasien karena keterbatasan fasilitas, peralatan ataupun ketenagaan yang sifatnya sementara atau menetap (PMK No. 001 Tahun 2012).

Kesiapan pelayanan dalam program BPJS masih banyak yang perlu diperhatikan terutama dalam system rujukan peserta BPJS di Puskesmas. Adapun yang menjadi penentu dalam kesuksesan program BPJS sebagaimana yang tercantum dalam Peraturan Menteri Kesehatan No. 75 Tahun 2014 yaitu ketersediaan sumber daya manusia misalnya Dokter atau tenaga kesehatan lainnya serta memiliki kompetensi di bidangnya masing- masing, ketersediaan sarana dan prasarana serta pembiayaan kesehatan di Puskesmas itu sendiri.

Penilaian terhadap pelaksanaan jaminan kesehatan nasional (BPJS) di Puskesmas dilihat dari 3 (tiga) indikator yaitu: angka kontak peserta BPJS di FKTP atau di Puskesmas, rasio rujukan rawat jalan non spesialistik dan rasio peserta Prolanis (Program Pengelolaan Penyakit Kronis) yang rutin berkunjung ke FKTP.

Berdasarkan data dari Dinas kesehatan Kabupaten Rokan Hulu diperoleh data sebagai berikut:

Tabel 1. Rekap Hasil Penilaian Kinerja FKTP sampai bulan September 2018

\begin{tabular}{|c|c|c|c|c|c|c|c|c|}
\hline \multirow[b]{2}{*}{ No } & \multirow[b]{2}{*}{ Puskesmas } & \multicolumn{2}{|c|}{ Rasio AK } & \multicolumn{2}{|c|}{ Rasio RPPB } & \multicolumn{2}{|c|}{ Rasio RNS } & \multirow{2}{*}{$\begin{array}{c}\% \\
\text { Pemba } \\
\text { yaran } \\
\text { Kapita } \\
\text { si }\end{array}$} \\
\hline & & Rata2 & $\begin{array}{c}\text { Penca } \\
\text { pa } \\
\text { Ian } \\
\end{array}$ & Rata2 & $\begin{array}{c}\text { Penca } \\
\text { pa } \\
\text { ian } \\
\end{array}$ & Rata2 & $\begin{array}{c}\text { Pencap } \\
\text { a } \\
\text { Ian } \\
\end{array}$ & \\
\hline 1 & Ujung Batu & 168,54 & Aman & 84 & Aman & 0,08 & Aman & $100 \%$ \\
\hline 2 & $\begin{array}{c}\text { Rambah Samo } \\
\text { I }\end{array}$ & 157,35 & Aman & 96,75 & Aman & 0,00 & Aman & $100 \%$ \\
\hline 3 & $\begin{array}{c}\text { Pendalian IV } \\
\text { Koto }\end{array}$ & 156,24 & Aman & 0,00 & $\begin{array}{l}\text { Tidak } \\
\text { Aman } \\
\end{array}$ & 0.00 & Aman & $95 \%$ \\
\hline 4 & Kepenuhan & 142,87 & $\begin{array}{l}\text { Tidak } \\
\text { Aman }\end{array}$ & 71,49 & Aman & 4,05 & Aman & $95 \%$ \\
\hline 5 & $\begin{array}{c}\text { Kunto } \\
\text { Darussalam }\end{array}$ & 120,32 & $\begin{array}{l}\text { Tidak } \\
\text { Aman }\end{array}$ & 52,87 & Aman & 0.00 & Aman & $95 \%$ \\
\hline 6 & Rambah & 21,88 & $\begin{array}{l}\text { Tidak } \\
\text { Aman }\end{array}$ & 58,33 & Aman & 0.00 & Aman & $95 \%$ \\
\hline 7 & Tandun I & 124,40 & $\begin{array}{l}\text { Tidak } \\
\text { Aman } \\
\end{array}$ & 25,49 & $\begin{array}{l}\text { Tidak } \\
\text { Aman } \\
\end{array}$ & 1,30 & Aman & $92,5 \%$ \\
\hline 8 & Tandun II & 95,67 & $\begin{array}{l}\text { Tidak } \\
\text { Aman }\end{array}$ & 42,36 & $\begin{array}{l}\text { Tidak } \\
\text { Aman }\end{array}$ & 0,78 & Aman & $92,5 \%$ \\
\hline 9 & $\begin{array}{l}\text { Rambah Hilir } \\
\text { II }\end{array}$ & 66,43 & $\begin{array}{l}\text { Tidak } \\
\text { Aman }\end{array}$ & 0.00 & $\begin{array}{l}\text { Tidak } \\
\text { Aman }\end{array}$ & 4,16 & Aman & $92,5 \%$ \\
\hline 10 & Kabun & 37,63 & $\begin{array}{l}\text { Tidak } \\
\text { Aman }\end{array}$ & 0.00 & $\begin{array}{l}\text { Tidak } \\
\text { Aman }\end{array}$ & 0.00 & Aman & $92,5 \%$ \\
\hline 11 & $\begin{array}{l}\text { Rokan IV } \\
\text { Koto }\end{array}$ & 25,79 & $\begin{array}{l}\text { Tidak } \\
\text { Aman }\end{array}$ & 39,22 & $\begin{array}{l}\text { Tidak } \\
\text { Aman }\end{array}$ & 0,90 & Aman & $92,5 \%$ \\
\hline 12 & $\begin{array}{c}\text { Rambah Samo } \\
\text { II }\end{array}$ & 16,98 & $\begin{array}{l}\text { Tidak } \\
\text { Aman }\end{array}$ & 0.00 & $\begin{array}{l}\text { Tidak } \\
\text { Aman }\end{array}$ & 0.00 & Aman & $92,5 \%$ \\
\hline 13 & $\begin{array}{l}\text { Tambusai } \\
\text { Utara I }\end{array}$ & 11,34 & $\begin{array}{l}\text { Tidak } \\
\text { Aman }\end{array}$ & 0.00 & $\begin{array}{l}\text { Tidak } \\
\text { Aman }\end{array}$ & 0.00 & Aman & $92,5 \%$ \\
\hline 14 & Tambusai & 10,35 & $\begin{array}{l}\text { Tidak } \\
\text { Aman }\end{array}$ & 0.00 & $\begin{array}{l}\text { Tidak } \\
\text { Aman }\end{array}$ & 0.00 & Aman & $92,5 \%$ \\
\hline 15 & $\begin{array}{l}\text { Kepenuhan } \\
\text { Hulu }\end{array}$ & 7,51 & $\begin{array}{l}\text { Tidak } \\
\text { Aman }\end{array}$ & 2,22 & $\begin{array}{l}\text { Tidak } \\
\text { Aman }\end{array}$ & 1,08 & Aman & $92,5 \%$ \\
\hline 16 & $\begin{array}{l}\text { Tambusai } \\
\text { Utara II }\end{array}$ & 3,33 & $\begin{array}{l}\text { Tidak } \\
\text { Aman }\end{array}$ & 0.00 & $\begin{array}{l}\text { Tidak } \\
\text { Aman }\end{array}$ & 1,19 & Aman & $92,5 \%$ \\
\hline
\end{tabular}




\begin{tabular}{|c|c|c|c|c|c|c|c|c|}
\hline \multicolumn{3}{|c|}{ Rokan IV } & \multicolumn{2}{|l|}{ Tidak } & \multicolumn{2}{|l|}{ Tidak } & \multirow[b]{2}{*}{ Aman } & \multirow[b]{2}{*}{$92,5 \%$} \\
\hline 17 & Koto II & 0.00 & Aman & 0.00 & Aman & 0.00 & & \\
\hline & Rambah Hilir & & Tidak & & Tidak & & Tidak & \\
\hline 18 & I & 17,21 & Aman & 3,51 & Aman & 5,95 & Aman & $90 \%$ \\
\hline 19 & Bangun Purba & 17,04 & $\begin{array}{l}\text { Tidak } \\
\text { Aman }\end{array}$ & 0.00 & $\begin{array}{l}\text { Tidak } \\
\text { Aman }\end{array}$ & 10,34 & $\begin{array}{l}\text { Tidak } \\
\text { Aman }\end{array}$ & $90 \%$ \\
\hline & Pagaran Tapah & & Tidak & & Tidak & & Tidak & \\
\hline 20 & Darussalam & 8,38 & Aman & 7,41 & Aman & 6,48 & Aman & $90 \%$ \\
\hline 21 & $\begin{array}{c}\text { Bonai } \\
\text { Darossam }\end{array}$ & 151 & $\begin{array}{l}\text { Tidak } \\
\text { Aman }\end{array}$ & 000 & $\begin{array}{l}\text { Tidak } \\
\text { Aman }\end{array}$ & 769 & $\begin{array}{l}\text { Tidak } \\
\text { Aman }\end{array}$ & $90 \%$ \\
\hline
\end{tabular}

Berdasarkan data di atas dapat dilihat bahwa pelaksanaan program BPJS di FKTP masih banyak yang belum mencapai target. Hal ini lah yang perlu di evaluasi bagaimana program BPJS terutama sistem rujukan yang diterapkan oleh Puskesmas Rambah Hilir I kepada peserta BPJS yang berkunjung ke Puskesmas.
Puskesmas Rambah Hilir I merupakan salah satu Puskesmas yang berada di Kecamatan Rambah Hilir I Kabupaten Rokan Hulu yang memiliki jumlah penduduk sebanyak. Berdasarkan hasil survey awal di Puskesmas Rambah Hilir I, diperoleh data sebagai berikut:

Tabel 2. Rekap kasus Rujukan di Puskesmas Rambah Hilir I Januari-Desember 2018

\begin{tabular}{ccc}
\hline No & Bulan & Pencapaian Rata2 \\
\cline { 3 - 3 } & & $\begin{array}{c}\text { Rasio Rujukan semua } \\
\text { kasus }\end{array}$ \\
$\mathbf{1 .}$ & & $58,3 \%$ \\
$\mathbf{2 .}$ & Januari & $51,6 \%$ \\
$\mathbf{3 .}$ & Pebruari & $52,6 \%$ \\
$\mathbf{4 .}$ & Maret & $23,6 \%$ \\
$\mathbf{5 .}$ & April & $26,3 \%$ \\
$\mathbf{6 .}$ & Mei & $14 \%$ \\
$\mathbf{7 .}$ & Juni & 27,3 \\
$\mathbf{8 .}$ & Juli & $26 \%$ \\
$\mathbf{9 .}$ & Agustus & $26 \%$ \\
$\mathbf{1 0 .}$ & September & $24,6 \%$ \\
$\mathbf{1 1 .}$ & Oktober & $18 \%$ \\
$\mathbf{1 2}$ & November & $17,3 \%$ \\
\hline
\end{tabular}

Berdasarkan data di atas dapat dilihat bahwa pelaksanaan rujukan bagi peserta BPJS di Puskesmas Rambah Hilir I masih dikategorikan tinggi sedangkan target rasio rujukan rawat jalan non spesialistik yang sudah ditentukan oleh pihak BPJS kepada Pihak Puskesmas yaitu kurang dari 5\%..

Masih tingginya angka rujukan rawat jalan non spesialistik bagi peserta BPJS di Puskesmas Rambah Hilir I sangat berpengaruh pada kinerja dan pelayanan Puskesmas itu sendiri. Hal ini lah yang menjadi alasan peneliti untuk mengetahui bagaimana sebenarnya pelaksanaan system rujukan di Puskesmas Rambah Hilir I Kabupaten Rokan
Hulu tahun 2018. Tujuan dari penelitian ini adalah untuk evaluasi pelaksanaan program BPJS khususnya dalam system rujukan rawat jalan non spesialistik menurut Permenkes nomor 75 tahun 2014 bagi peserta BPJS di Puskesmas Rambah Hilir I Kabupaten Rokan Hulu tahun 2018.

\section{METODE}

Penelitian ini menggunakan metode kualitatif. Penelitian dilakukan di Puskesmas Rambah Hilir I Kabupaten Rokan Hulu dimulai dari Bulan Januari-Pebruari 2019. Subjek dalam penelitian ini berjumlah 3 orang terdiri dari Kepala Puskesmas, 
Pengelola Program dan peserta rujukan.Instrumen penelitian merupakan alatalat yang akan digunakan untuk pengumpulan data. Instrumen ini dapat berupa kuesioner, formulir observasi, formulir-formulir yang berkaitan dengan pencatatan data dan sebagainya.
HASIL

Hasil Penelitian dari Observasi

Dari hasil observasi yang dilakukan peneliti di Puskesmas Rambah Hilir I adalah sebagai berikut:

Tabel 3. Pedoman Observasi Di Puskesmas Rambah Hilir I Kabupaten Rokan Hulu Tahun 2018

\begin{tabular}{|c|c|c|c|c|}
\hline \multirow{2}{*}{ No } & \multirow{2}{*}{ Kriteria Penerapan } & \multicolumn{2}{|c|}{ Penerapan } & \multirow{2}{*}{ Keterangan } \\
\hline & & $\mathbf{Y a}$ & Tidak & \\
\hline \multirow[t]{3}{*}{1.} & Petugas/ SDM & & & \\
\hline & a. sesuai dengan standar & & $\sqrt{ }$ & \\
\hline & $\begin{array}{l}\text { b. Memiliki kompetensi di } \\
\text { bidangnya }\end{array}$ & & $\sqrt{ }$ & \\
\hline \multirow[t]{4}{*}{2.} & Sarana dan prasarana & & & \\
\hline & a. Sesuai dengan standar & & $\sqrt{ }$ & \\
\hline & b. Digunakan sesuai dengan & $\sqrt{ }$ & & \\
\hline & c. Mudah dijangkau & $\sqrt{ }$ & & \\
\hline \multirow[t]{4}{*}{3.} & Obat-obatan & & & \\
\hline & a. Tersedia sesuai kebutuhan & & $\sqrt{ }$ & \\
\hline & b. Di kelola secara baik & $\sqrt{ }$ & & \\
\hline & c. Digunakan sesuai diagnosa & $\sqrt{ }$ & & \\
\hline \multirow[t]{3}{*}{4.} & $\begin{array}{l}\text { Pelaksanaan sistem rujukan rawat } \\
\text { jalan non-spesialistik di Puskesmas } \\
\text { Rambah Hilir I }\end{array}$ & & & \\
\hline & a. Dilakukan sesuai alur rujukan & $\sqrt{ }$ & & \\
\hline & b. Pencatatan dan pelaporan & $\sqrt{ }$ & & \\
\hline \multirow[t]{3}{*}{5.} & $\begin{array}{l}\text { Evaluasi pelaksanaan sistem rujukan } \\
\text { rawat jalan non spesialistik di } \\
\text { Puskesmas Rambah hilir I }\end{array}$ & & & \\
\hline & $\begin{array}{l}\text { a. Adanya evaluasi program dengan } \\
\text { pihak terkait }\end{array}$ & $\sqrt{ }$ & & \\
\hline & b. Adanya tindak lanjut/ feedback & $\sqrt{ }$ & & \\
\hline
\end{tabular}

Sumber: Data Primer Puskesmas Rambah Hilir I Tahun 2018

Berdasarkan tabel 3 di atas dan hasil observasi penulis selama melakukan penelitian di Puskesmas Rambah Hilir I, dapat dilihat bahwa SDM di Puskesmas Rambah Hilir I belum sesuai dengan Permenkes Nomor 75 Tahun 2014. Hal ini dapat dilihat dari segi penempatan, tanggung jawab yang belum sesuai dengan kompetensi yang dimiliki. Penempatan yang belum merata menjadi penyebab munculnya masalah belum tercapainya kualitas dan kuantitas SDM sesuai dengan standar yang berlaku. Jumlah tenaga memang banyak namun kebanyakan merupakan tenaga suka rela (TKS). Kemudian tenaga sanitasi, tenaga kesehatan masyarakat (Promkes) dan gizi juga masih dibutuhkan.

Dari segi sarana dan prasarana juga masih belum sesuai dengan standar yang telah ditetapkan. Seperti masih ada alat-alat yang seharusnya sudah diganti tetapi masih tetap digunakan. Namun dari segi keterjangkauan Puskesmas Rambah Hilir I masih bisa dijangkau oleh masyarakat karena Puskesmas berada di pusat kecamatan dan dekat dengan pemukiman.

Ketersediaan obat-obatan di Puskesmas 
Rambah Hilir I juga masih terbatas, pemberian obat-obatan sudah sesuai dengan diagnose Dokter. Penyimpanan obat sudah tertata dengan baik.

Dalam hal pelaksanaan system rujukan, rujukan sudah sesuai dengan alur yang telah ditetapkan, namun masalahnya masih banyak rujukan karena permintaan dari pasien sendiri. Pencatatan dan pelaporan dilakukan oleh Pcare setiap bulan dan dilaporkan ke pihak BPJS melalui aplikasi online.

Untuk evaluasi program di Puskesmas selalu dilakukan setiap 6 (enam) bulan sekali untuk melihat sejauh mana program dilaksanakan. Dan feedback seperti sosialisasi ke lintas sector sudah dilakukan oleh Puskesmas Rambah Hilir I.

\section{Hasil Penelitian dari Wawancara}

Pada penelitian ini penulis melakukan wawancara terhadap 4 (emapat) orang informan yang terdiri dari 1 (satu) orang Kepala Puskesmas, 1(satu) orang Pcare, 2 (dua) orang pasien rujukan. Informan dalam penelitian ini berumur antara 28-38tahun.

Tabel 4. Karakteristi Informan

\begin{tabular}{ccccc}
\hline No & Informan & $\begin{array}{c}\text { Kode } \\
\text { Informan }\end{array}$ & Jenis Kelamin & Pendidikan \\
\hline 1. & Kepala Puskesmas & Kp & Perempuan & S1 \\
2. & Pcare & Pc & Perempuan & D-III \\
3. & Pasien & P1 & Laki-laki & S1 \\
4 & Pasien & P2 & Perempuan & SMA \\
\hline
\end{tabular}

Sumber: Data Primer Penelitian di Puskesmas Rambah Hilir I

\section{SDM}

Berdasarkan wawancara terhadap informan dikteahui ketersediaan SDM di Puskesmas Rambah Hilir I masih belum sesuai dengan kebutuhan dan dari segi penempatan dan tanggung jawab belum sesuai dengan kompetensi yang dimiliki.

\section{Sarana dan Prasarana}

Berdasarkan hasil wawancara terhadap informan utama dan pendukung, terkait dengan sarana dan prasarana diketahui sarana dan prasarana di Puskesmas Rambah Hilir I sebenarnya masih belum sesuai dengan standar yang ada. Puskesmas masih banyak kekurangan terutama ruangan, namun apa yang tersedia di puskesmas selama masih bisa diberdaya akan diberdayakan mengingat kondisi yang ada. Kalau untuk keterjangkauan karena Puskesmas ini memiliki 8 desa ada beberapa desa yang harus melewati aliran sungai untuk sampai ke Puskesmas induk. Namun untuk memudahkan akses pelayanan kesehatan masih ada Pustu yang buka di setiap desanya sehingga masyarakat tidak perlu ke puskesmas induk untuk mendapatkan pelayanan kesehatan cukup di Pustu saja sudah bisa.

\section{Obat-obatan}

Ketersediaan obat-obatan Puskesmas sebenarnya masih kekurangan, tetapi karena adanya dana BPJS dapat mendukung penyediaan obat-obatan di Puskesmas walaupun tidak sepenuhnya tapi setidaknya membantu pembiayaan penyediaan obatobatan di Puskesmas Rambah Hilir I ini. Kemudian pemberian obat kepada pasien diberikan sesuai dengan diagnose yang telah ditentukan dan sesuai dengan kebutuhan.

\section{Pelaksanaan Sistem Rujukan}

Berdasarkan hasil wawancara yang dilakukan kepada informan mengenai "Bagaimana pelaksanaan system rujukan di Puskesmas Rambah Hilir I, apakah sudah sesuai dengan alur yang telah ditetapkan?"

Informan 2 (Pc) menjawab:

"Pelaksanaan system rujukan rawat jalan non spesialistik sudah dilakukan sesuai dengan alur, misalnya pasien datang ke Puskesmas dengan membawa kartu BPJS kemudian mendaftar di bagian pendaftaran, selanjutnya pasien ke poli pelayanan disana pasien diperiksa dan didiagnosa Dokter, kemudian pasien melaporkan ke saya selaku Pcare untuk melihat apakah pasien tersebut dirujuk atau hanya rawat jalan, kalau pasien dirujuk akan disiapkan surat rujukannya dan 
saya selaku Pcare langsung mengentri data pasien rujukan di aplikasi BPJS online" (Pc).

Hal ini sama dengan Pasien 1 (pc) yang mengatakan:

"Nah pertama saya datang saya langsung menuju ke bagian pendaftaran dengan menunjukkan kartu BPJS saya, kemudian saya di arahkan ke bagian poli umum untuk diperiksa, selanjutnya Dokter menentukan penyakit saya kemudian saya di arahkan kembali ke bagian pendaftaran, selanjutnya petugas memberikan saya surat rujukan" (P1). Sedangkan Pasien 2 (P2) menjawab:

"pertama saya langsung ke bagian pendaftaran, saya menunjukkan kartu BPJS, kemudian saya langsung menuju ke poli Umum untuk diperiksa Dokter, setelah Dokter menentukan penyakit saya kemudian saya memberikan hasil pemeriksaan ke bagian depan bagian pendaftaran, kemudian mereka mengeluarkan surat rujukan untuk saya" (P2).

Pelaksanaan system rujukan rawat jalan non spesialistik di Puskesmas Rambah Hilir I sudah sesuai dengan alur rujukan BPJS di Puskesmas.

Berdasarkan hasil wawancara yang dilakukan kepada informan mengenai "Kenapa angka rujukan di Puskesmas Rambah Hilir I masih tinggi? Apakah karena anjuran dari Dokter atau permintaan pasien sendiri?"

Informan $1(\mathrm{Kp})$ mengatakan:

"Tingginya angka rujukan di Puskesmas Rambah Hilir I dikarenakan banyaknya pemintaan pasien, Kita tau bahwa Puskesmas Rambah Hilir I ini dekat dengan Kabupaten, banyak masyarakat yang beranggapan bahwa kalau mereka dirujuk mereka langsung mendapat pelayanan ke Dokter spesialis, pada hal kita tahu bahwa ada 144 penyakit yang sebenarnya tidak boleh dirujuk karena masih bisa ditangani di Puskesmas, jadi kalau pasien melakukan control ulang ke Rumah sakit pasien akan meminta rujukan kembali ke Puskesmas, nah ini lah yang mengakibatkan tingginya angka rujukan rawat jalan di Puskesmas Rambah hilir I ini" (Kp).

Informan 2 (Pc) menanggapi hal yang sama dengan mengatakan:

"Sebenarnya rujukan pasien sesuai dengan indikasi medis, namun lebih banyak ke permintaan sendiri, banyak pasien yang meminta rujukan pada hal sebenarnya masih bias ditangani di Puskesmas, kemudian rujukan ini sebenarnya berlaku selama 3 (tiga) bulan, namun pada saat pasien ingin melakukan control ulang banyak pasien yang meminta rujukan kembali ke Puskesmas dengan alasan surat rujukannya hilang, itu lah yang mengakibatkan tingginya angka rujukan di puskesmas ini" (Pc).

Pasien 1 (P1) menjawab:

"Saya melakukan rujukan di Puskesmas Rambah Hilir I karena saya ingin berobat ke Dokter Spesialis di Rumah sakit. Saya merasa kalau saya berobat ke Dokter spesialis penyakit yang saya derita lebih cepat diketahui dan cepat diobati" (P1).

Sedangkan Pasien 2 (P2) mengatakan:

"Saya meminta rujukan karena keinginan sendiri, karena Rumah sakit dekat dari sini saya lebih memilih langsung berobat ke rumah sakit saja” (P2).

Banyaknya permintaan pasien untuk dirujuk mengakibatkan tingginya angka rujukan di Puskesmas sehingga masuk ke dalam zona tidak aman. Hal ini juga akan berpengaruh pada kinerja Puskesmas Rambah Hilir I.

Tindak Lanjut/ feedback dari belum tercapainya target pelaksanaan system Rujukan

Berdasarkan hasil wawancara yang dilakukan kepada informan mengenai "Bagaimana tindak lanjut/ feedback yang bisa dilakukan oleh pihak Puskesmas dalam menurunkan angka rujukan?

Informan $1(\mathrm{Kp})$ mengatakan:

"Kami sudah menyampaikan kepada lintas sector secara langsung dan juga sudah disosialisasikan ke masyarakat bahwa di Puskesmas ini sudah ada Dokter dan disini juga sudah ada obat, jadi selagi masih bisa kami tangani sebenarnya pasien tidak perlu dirujuk. Kemudian kami berharap untuk ke depannya kami lebih giat lagi mensosialisasikan kepada lintas sector dan juga kepada masyarakat karena masih banyak masyarakat yang beranggapan bahwa di Puskesmas tidak ada Dokter yang ada hanya perawat atau Bidan pada hal kan di Puskesmas sudah ada Dokter yang menangani" $(\mathrm{Kp})$.

Informan 2 (Pc) menanggapi pertanyaan tersebut dengan mengatakan:

"Kalau menurut saya supaya pelaksanaan program BPJS terutama system rujukan terlaksana sesuai dengan yang telah ditetapkan Perlu dilakukan pelatihan bersama dengan Dokter juga supaya program lebih 
sinkron, jadi Dokter juga perlu menekankan kepada pasien bahwa penyakit yang masih bisa ditangani di Puskesmas tidak perlu dirujuk ke Rumah sakit karena Puskesmas juga menyediakan obat-obatan yang dibutuhkan. $(P c)$.

Informan 3 (P1) mengatakan:

"Harapan saya kepada Puskesmas Rambah Hilir I supaya memberikan pelayanan lebih baik lagi, Dokternya dapat memeriksa penyakit yang diderita dan obat-obatan juga tersedia di Puskesmas" (P1).

Sedangkan Informan 4 (P2) menjawab:

"saya berharap Puskesmas lebih banyak penyuluhan ke masyarakat karena sepertinya masih banyak yang belum tau pelayanan di Puskesmas itu seperti apa, Dokternya bagaimana ketersediaan obatnya seperti apa" (P2).

Pada intinya Puskesmas Rambah Hilir I perlu mensosialisasikan ke masyarakat tentang pelayanan apa saja yang bisa dilakukan di Puskesmas. Terutama dalam memberikan pelayanan kesehatan. Menyediakan tenaga kesehatan yang lengkap dan kompeten di bidangnya, menyediakan sarana dan prasarana yang memadai, menyediakan obat-obatan yang dibutuhkan Jika Puskesmas sudah melengkapi semua fasilitas kesehatan otomatis angka rujukan pasien bisa menurun dan pelaksanaan system rujukan rawat jalan terlaksana sesuai dengan indikasi sehingga program BPJS terlaksana dengan baik untuk ke depannya.

\section{PEMBAHASAN \\ Ketersediaan SDM di Puskesmas Rambah Hilir I}

Berdasarkan hasil wawancara mengenai evaluasi pelaksanaan system rujukan rawat jalan non-spesialistik bagi peserta BPJS di Puskesmas Rambah Hilir I, dapat diketahui bahwa ketersediaan SDM di Puskesmas Rambah Hilir I masih belum sesuai dengan Permenkes Nomor 75 Tahun 2014 bahwa Puskesmas setidaknya memiliki 2 Dokter.

Dan dari hasil observasi yang telah dilakukan dapat dilihat dari segi penempatan, tanggung jawab yang belum sesuai dengan kompetensi yang dimiliki. Penempatan yang belum merata menjadi penyebab munculnya masalah belum tercapainya kualitas dan kuantitas SDM sesuai dengan standar yang berlaku.

Hal ini sejalan dengan penelitian yang dilakukan oleh Nining Talib (2017) dalam penelitiannya menyebutkan bahwa keterbatasan SDM berpengaruh terhadap pelayanan kesehatan dan pelaksanaan rujukan pasien BPJS di Puskesmas.

Sumber daya manusia adalah individu yang bekerja sebagai penggerak suatu organisasi, baik institusi ataupun perusahaan dan berfungsi sebagai asset yang harus dilatih dan dikembangkan kemampuannya. Sumber daya manusia dapat dinilai dari segi kualitas dan kuantitasnya. Kuantitas SDM menyangkut jumlah SDM (penduduk) sedangkan kualitas menyangkut mutu sumber daya manusia tersebut, yang menyangkut kemampuan nonfisik (kecerdasan dan mental).

Oleh karena itu dapat disimpulkan bahwa tingginya angka rujukan rawat jalan non-spesialistik di Puskesmas Rambah Hilir I dipengaruhi oleh kurangnya ketersediaan SDM terutama tenaga Dokter, karena dalam hal ini Dokter sangat berpengaruh terhadap pelayanan kesehatan dan pelaksanaan rujukan di Puskesmas Rambah Hilir I. Untuk itu diharapkan Pihak Puskesmas dapat mengusulkan penyediaan Tenaga kesehatan terutama Dokter kepada Pihak terkait yaitu Dinas Kesehatan sehingga pelaksanaan pelayanan kesehatan berjalan sesuai dengan yang diharapkan, terutama mengenai system rujukan yang dapat dikelola dengan baik sehingga Puskesmas Rambah Hilir I memenuhi target rujukan sesuai dengan ketentuan yang telah ditetapkan.

\section{Ketersediaan Sarana dan prasarana}

Berdasarkan hasil wawancara terhadap informan dan observasi yang telah dilakukan dapat diketahui bahwa ketersediaan sarana dan prasarana di Puskesmas Rambah Hilir I belum sesuai dengan Permenkes Nomor 75 Tahun 2014. Peralatan di Puskesmas harus memenuhi persyaratan seperti standar mutu, keamanan, keselamatan, memiliki izin edar sesuai dengan ketentuan peraturan perundang-undangan dan diuji serta dikalibrasi secara berkala oleh institusi penguji dan pengkalibrasian yang berwenang. Sedangkan untuk Puskesmas Rambah Hilir I sendiri dari ketersediaan bangunan yang masih minim, Puskesmas Rambah Hilir I menggunakan aula sebagai IGD Puskesmas. Namun disamping itu sarana dan prasarana yang ada di Puskesmas masih bisa diberdayakan dan masih bisa digunakan sesuai dengan fungsinya.

Selain itu Puskesmas Rambah Hilir I 
juga masih bisa dijangkau oleh masyarakat. Walaupun masih ada desa yang harus menyeberangi sungai untuk sampai ke puskesmas induk namun masih ada Pustu yang siap melayani masyarakat.

Penelitian Nining Talib (2017) mengemukan bahwa ketersediaan fasilitas kesehatan yang memadai dapat meningkatkan kinerja puskesmas dalam melakukan pemeriksaan kepada pasien dan merupakan suatu keharusan untuk proses rujukan yang dilakukan akibar keterbatasan sarana tersebut. Jika sarana dan prasarana kurang lengkap maka proses mendiagnosis pasien akan terganggu dan hal ini menyebabkan petugas kesehatan harus merujuk pasien ke rumah sakit sehingga akan berdampak peningkatan rujukan pasien pada rumah sakit penerima rujukan tersebut.

Hal ini juga sejalan dengan penelitian Josua Tobing (2015) yang mengemukan bahwa jika kekurangan fasilitas alat medis di pelayanan primer akan membuat pasien merasa tidak puas dan kecewa sehingga berdampak pada tingginya angka rujukan atau akan terjadi rujukan ke rumah sakit.

Sarana merupakan segala sesuatu yang dapat dipakai sebagai alat dalam mencapai maksud dan tujuan. Sedangkan prasarana yaitu segala sesuatu yang merupakan penunjang utama terselenggaranya suatu proses (usaha, pembangunan, proyek). Ketersediaan sarana dan prasarana dalam pelayanan kesehatan merupakan hal yang sangat penting guna mencapai penegakan diagnose dan pelaksanaan tindakan yang tepat.

Oleh karena itu dapat disimpulkan bahwa keterbatasan sarana dan prasarana di Puskesmas Rambah Hilir I merupakan penyebab tingginya angka rujukan di Puskesmas Rambah Hilir I. Diharapkan Puskesmas Rambah Hilir I dapat menyediakan sarana dan prasarana baik itu berupa ruangan ataupun alat kesehatan yang menunjang pelaksanaan pelayanan kesehatan sehingga Puskesmas dapat memberikan pelayanan secara maksimal sesuai dengan kompetensi Puskesmas tanpa harus merujuk pasien.

\section{Ketersediaan Obat-obatan}

Berdasarkan wawancara terhadap informan dapat diketahui bahwa ketersediaan obat-obatan di Puskesmas Rambah Hilir I masih terbatas, masih ada obat-obatan yang belum tersedia di Puskesmas. Sebenarnya pengadaan obat-obatan di Puskesmas berdasarkan permintaan ke pihak Dinas kesehatan Kabupaten, namun pihak Puskesmas masih merasa belum tercukupi. Dikarenakan adanya program BPJS jadi dana BPJS bisa sedikit membantu dalam hal pengadaan obatobatan di Puskesmas. Jika obat habis pihak Puskesmas dapat segera menyediakan obat tersebut.

Dari penelitian Nining Talib (2017) dijelaskan bahwa jika obat-obatan yang dibutuhkan tidak tersedia di Puskesmas maka akan diganti dengan obat-obatan lain. Jika obat pengganti tidak ada maka akan diberi rujukan untuk mendapat pengobatan yang sesuai.

Hal ini juga sejalan dengan penelitian Josua Tobing (2015) bahwa banyak pasien yang seharusnya bisa diberikan pelayanan di Puskesmas namun harus dirujuk karena keterbatasan obat-obatan di Faskes.

Berdasarkan UU nomor 36 tentang kesehatan pasal 36 ayat 1 menyebutkan bahwa Pemerintah menjamin ketersediaan, pemerataan dan keterjangkauan pembekalan kesehatan terutama obat esensial. Namun kenyataannya di lapangan masih ada Obatobatan yang belum tersedia di Puskesmas. Obat merupakan bahan yang dibutuhkan untuk penetapan diagnosis, pencegahan, penyembuhan, pemulihan, peningkatan kesehatan dan kontrasepsi untuk manusia. Untuk itu penyediaan obat-obatan di Puskesmas harus diperhatikan demi terselenggaranya pelayanan kesehatan kepada pasien dan mempengaruhi angka rujukan pasien di Puskesmas itu sendiri, Oleh karena itu dapat disimpulkan bahwa tingginya angka rujukan di Puskesmas Rambah Hilir I disebabkan terbatasnya obat-obatan di Puskesmas Rambah Hilir I. Diharapkan untuk kedepannya Puskesmas Rambah Hilir I menyediakan obat-obatan yang dibutuhkan sesuai dengan kebutuhan pasien sehingga angka rujukan dapat ditekan dan Puskesmas Rambah Hilir I mencapai target rujukan sesuai dengan ketentuan yang berlaku.

\section{Pelaksanaan Sistem Rujukan Rawat Jalan Non-Spesialistik Bagi Peserta BPJS Di Puskesmas Rambah Hilir I}

Berdasarkan hasil wawancara terhadap informan dan observasi yang dilakukan bahwa alur rujukan yang dilakukan pasien di Puskesmas Rambah Hilir I sudah sesuai dengan alur rujukan yang berlaku, dimana 
pasien peserta BPJS melakukan pendaftaran terlebih dahulu dengan memperlihatkan kartu BPJS kepada petugas dan selanjutnya petugas mengarahkan pasien ke poli yang bersangkutan, setelah pasien diperiksa dan didiagnosa oleh Dokter selanjutnya pasien diarahkan kembali ke meja pendaftaran dan memberikan status pasien kepada petugas Pcare, kemudian jika pasien harus dirujuk maka petugas akan mengeluarkan surat rujukan kepada pasien.

Dari segi pencatatan dan pelaporan system rujukan, Pcare Puskesmas Rambah Hilir I sudah menjalankan aplikasi BPJS online yang terhubung langsung dengan pihak BPJS. Pasien yang datang berkunjung ke Puskesmas akan langsung dientri ke aplikasi begitu juga dengan pasien rujukan. Pelaporan dilakukan setiap bulan kepada pihak terkait dan akan dievaluasi setiap 3 (tiga) bulan sekali. Jika rasio rujukan melebihi dari target yang telah ditentukan maka akan berdampak pada kinerja Puskesmas itu sendiri sehingga biaya kapitasi Puskesmas akan dipotong.

Kemudian dari segi pelaksanaan system rujukan tingginya angka rujukan di Puskesmas Rambah Hilir I dikarenakan permintaan pasien itu sendiri. Pasien yang melakukan rujukan beranggapan bahwa sarana dan prasarana di Puskesmas masih kurang sehingga mereka lebih mempercayai Rumah sakit untuk melakukan pemeriksaan. Selain itu pasien yang sudah dirujuk meminta kembali surat rujukan kepada pihak Pukesmas dengan alasan harus control ulang pada hal surat rujukan tersebut berlaku selama 3 (tiga) bulan, namun karena alasan hilang dan sebagainya menyebabkan pihak Puskesmas harus mengeluarkan surat rujukan kembali.

$$
\text { Penelitian Nining Talib }
$$
menyebutkan bahwa BPJS Kesehatan telah menetapkan target rujukan yaitu dibawah 5\%, untuk itu Puskesmas sebagai penapis rujukan pelayanan kesehatan perlu di tingkatkan lagi. Penelitiannya juga mengemukan bahwa fungsi Puskesmas yaitu sebagai barisan terdepan dengan kata lain sebagai pelaksana kebijakan yang dibuat oleh pemerintah dalam memberikan pelayanan kesehatan kepada masyarakat. Oleh karena itu fungsi Puskesmas sebagai penapis rujukan pelayanan kesehatan perlu ditingkatkan lagi.

Sesuai dengan Kemenkes tahun 2012 rujukan kesehatan berkaitan dengan upaya pencegahan dan peningkatan kesehatan (sarana, teknologi dan operasional). Untuk itu Puskesmas sebagai pelaksana kebijakan memberikan pelayanan kepada masyarakat dengan mendahulukan upaya preventif dan promotif tanpa mengabaikan upaya kuratif dan rehabititatif. Berdasarkan kesepakatan dari pihak BPJS bahwa Puskesmas tidak boleh melakukan rujukan jika masih bisa ditangani di Puskesmas. Ada 144 diagnosa penyakit yang tidak boleh dirujuk ke faskes lanjutan. Sedangkan untuk target rujukan rawat jalan Puskesmas harus dibawah 5\%.

Oleh karena itu dapat disimpulkan bahwa Puskesmas Rambah Hilir I sudah melakukan alur rujukan sesuai dengan alur rujukan yang telah ditetapkan, namun masih banyak rujukan yang berasal dari permintaan pasien sehingga dapat menyebabkan tingginya rasio rujukan rawat jalan non spesialistik di Puskesmas Rambah Hilir I. Sedangkan untuk pencatatan dan pelaporan Puskesmas Rambah Hilir I selalu melaporkan pasien rujukan melalui aplikasi Pcare yang terhubung langsung dengan pihak BPJS kesehatan.

Diharapkan Puskesmas Rambah Hilir I yang berwenang dalam memberikan rujukan kepada pasien untuk lebih tegas dalam mengambil keputusan terkait pelaksanaan rujukan pasien, sehingga pasien yang dirujuk masuk dalam kategori yang harus dirujuk dan angka rujukan di Puskesmas dapat diturunan untuk kedepannya.

\section{Tindak Lanjut/ feedback dari belum tercapainya target pelaksanaan sIstem Rujukan}

Berdasarkan wawancara yang dilakukan kepada informan adapun tindak lanjut yang telah dilakukan oleh pihak Puskesmas dalam menurunkan angka rujukan di Puskesmas yaitu melakukan sosialisasi kepada Lintas sector dan masyarakat bahwa di Puskesmas sudah tersedia Dokter dan obatobatan juga, untuk itu selama Puskesmas masih bisa menangani pasien maka pihak Puskesmas tidak boleh mengeluarkan surat rujukan kepada pasien kecuali dalam keadaan darurat.

Dari hasil observasi yang dilakukan Puskesmas Rambah Hilir I melaksanakan evaluasi program BPJS setiap 3 (tiga) bulan sekali untuk melihat kinerja Puskesmas itu sendiri dan Puskesmas sendiri juga sudah melakukan tindak lanjut dalam mengatasi masalah rujukan tersebut. 
Berdasarkan Permenkes Nomor 80 tahun 2012 tentang pedoman pelakssanaan Program jaminan kesehatan nasional menyebutkan bahwa kendala pelaksanaan jaminan kesehatan yang masih terjadi yaitu system rujukan yang belum berjalan secara optimal. Puskesmas sebagai pelaksana kebijakan sekaligus menjalankan upaya promotif dan preventif tanpa mengabaikan upaya kuratif dan rehabilitative.

Oleh karena itu dapat disimpulkan bahwa Puskesmas Rambah Hilir I telah melakukan tindak lanjut dalam menurunkan angka rujukan berupa sosialisasi kepada lintas sector dan masyarakat mengenai bagaimana ketersediaan SDM berupa Dokter dan tenaga medis serta sudah tersedia obat-obatan yang dibutuhkan oleh masyarakat. Diharapkan Puskesmas Rambah Hilir I bukan hanya mensosialisasikan kepada masyarakat tetapi juga menyediakan SDM, sarana dan prasarana serta obat-obatan yang berkualitas untuk masyarakat sehingga pasien terlayani di Puskesmas tanpa harus dirujuk.

\section{KESIMPULAN}

Berdasarkan hasil penelitian dan pembahasan tentang Evaluasi Pelaksanaan Sistem Rujukan Rawat Jalan Non-Spesialistik Bagi Peserta BPJS di Puskesmas Rambah Hilir I Tahun 2018, maka penulis menarik kesimpulan bahwa:

Ketersediaan SDM di Puskesmas Rambah Hilir I belum sesuai dengan Permenkes Nomor 75 Tahun 2014. Dilihat dari segi penempatan, tanggung jawab yang belum sesuai dengan kompetensi yang dimiliki merupakan masalah yang dihadapi oleh Puskesmas Rambah Hilir I. Hal ini lah yang mempengaruhi tingginya angka rujukan ke faskes lanjutan di Puskesmas Rambah Hilir I.

Ketersediaan sarana dan prasarana di Puskesmas Rambah Hilir I belum sesuai dengan Permenkes Nomor 75 Tahun 2014. Jumlah ruangan yang masih terbatas serta alat kesehatan yang masih perlu di tambah merupakan hal yang perlu diperhatikan. Alasan ini lah yang menjadi tingginya angka rujukan di Puskesmas Rambah Hilir I.

Ketersediaan obat-obatan di Puskesmas Rambah Hilir I masih terbatas, masih ada obatobatan yang pengadaannya belum tercukupi di Puskesmas. Hal ini mempengaruhi tingginya angka rujukan di Puskesmas Rambah Hilir I karena pasien harus di rujuk dengan alasan tidak tersedianya obat-obatan.

Pelaksanaan system rujukan di Puskesmas Rambah Hilir I sudah dilaksanakan sesuai dengan alur rujukan, namun masih banyak kasus rujukan berdasarkan permintaan pasien sendiri, hal inilah yang mempengaruhi tingginya angka rujukan di Puskesmas Rambah Hilir I.

Tindak lanjut/ feedback yang telah dilakukan oleh pihak Puskesmas dalam menurunkan angka rujukan di Puskesmas yaitu dengan melakukan sosialisasi kepada Lintas Sektor dan masyarakat mengenai pelayanan yang bisa didapatkan di Puskesmas, menekankan kepada masyarakat bahwa selama Puskesmas masih bisa melayani penyakit yang diderita pasien maka pasien tidak perlu di rujuk ke Rumah sakit kecuali dalam keadaan darurat. Meningkatkan pelayanan kesehatan di Puskesmas dengan meyediakan tenaga Dokter dan juga obat-obatan di Puskesmas.

\section{SARAN}

Berdasarkan kesimpulan di atas, maka saran yang bisa diberikan antaralain:

Diharapkan adanya penambahan SDM terutama Dokter di Puskesmas Rambah Hilir I supaya pasien dapat terlayani sepenuhnya sesuai dengan diagnose yang telah ditetapkan. Perlu diperhatikan penempatan, kompetensi dan tanggung jawab dari SDM itu sendiri untuk kedepannya.

Diharapkan Puskesmas Rambah Hilir I dapat melengkapi sarana dan prasarana untuk kedepannya, alat kesehatan yang rusak atau belum tersedia di Puskesmas dapat di ganti supaya pelayanan medis yang diberikan kepada pasien lebih maksimal, sehingga angka rujukan dapat diturunkan untuk kedepannya.

Diharapkan Puskesmas Rambah Hilir I dapat menyediakan obat-obatan yang dibutuhkan pasien di Puskesmas sehingga dapat menumbuhkan kepercayaan kepada pasien, dan angka rujukan dapat diturunkan untuk kedepannya.

Diharapkan Puskesmas Rambah Hilir I yang berwenang dalam memberikan rujukan kepada pasien untuk lebih tegas dalam mengambil keputusan terkait pelaksanaan rujukan pasien, sehingga pasien yang dirujuk masuk dalam kategori yang harus dirujuk bukan karena permintaan sendiri. Dengan begitu maka angka rujukan di Puskesmas Rambah Hilir I dapat diturunkan untuk kedepannya. 
Diharapkan Puskesmas Rambah Hilir I banyak melakukan pendekatan kepada masyarakat mengenai pelayanan apa saja yang bisa diberikan di Puskesmas, karena masih banyak masyarakat yang belum tau bahwa Puskesmas sudah menyediakan tenaga Dokter dan obat-obatan yang pelayanannya bisa dijangkau oleh masyarakat.

Diharapkan Dinas Kesehatan menanggapi mengenai ketersediaan SDM, sarana dan prasarana serta obat-obatan di Puskesmas Rambah Hilir I.

Dan untuk pihak BPJS dan Dinas Kesehatan supaya melakukan tindak lanjut/ mengirimkan feedback kepada pihak Puskesmas sehingga pihak Puskesmas mengetahui berapa pencapaian indicator angka rujukan rawat jalan non-spesialistik dalam setiap 6 (enam) bulan sekali dan melakukan evaluasi program minimal 1 (satu) kali dalam setahun.

\section{DAFTAR PUSTAKA}

Ayuningtyas Dumilah, (2015). Kebijakan Kesehatan. Jakarta: Rajawali Pers

BPJS Kesehatan. (2014). Dana Kapitasi BPJS Kesehatan.

BPJS Kesehatan. Panduan Praktis Sistem Rujukan Berjenjang.

Budiono Agus. Evaluasi Implementasi Pelayanan Jaminan Kesehatan Nasional Pada Balai Kesehatan Paru Masyarakat (BKPM) Wilayah Semarang Terikat Kerja Sama dengan Badan Penyelenggara Jaminan Sosial (BPJS Kesehatan). Jurnal Manajemen Kesehatan Indonesia Vol.04 No.01. (2016). Fakultas Kesehatan Masyarakat Universitas Diponegoro.

Hastuti Permata R, dkk. (2016). Asuransi Konvensional Syariah dan BPJS. Yogyakarta: Parama Publishing.

Indrianingrum Irawati, dkk. Input System Rujukan Badan Penyelenggara Jaminan Social (BPJS) Kesehatan Fasilitas Kesehatan Tingkat Pertama (FKTP) Kabupaten Jepara Vol 2 No. 2 (2017). STIKes Muhammadiyah Universitas Negeri Semarang

Kementerian Kesehatan Republik Indonesia. (2015). Buku Pegangan Sosialisasi Jaminan Kesehatan Nasional (JKN) dalam Sistem Jaminan SosialNasional.
Kurnia Roni. (2018). Penerapan KBK pada FKTP JKN. Jakarta: BPJS Kesehatan.

Notoatmodjo Soekidjo. (2012). Metodologi Penelitian Kesehatan. Jakarta: Rineka Cipta.

Peraturan Menteri Kesehatan Republik Indonesia Nomor 10 Tahun 2017

Tentang Petunjuk Operasional Penggunaan Dana Alokasi Khusus Fisik Bidang kesehatan Tahun Anggaran 2017.

Peraturan Menteri Kesehatan Republik Indonesia Nomor 75 Tahun 2014 Tentang Pusat Kesehatan Masyarakat.

Peraturan Bersama Sekretaris Jenderal Kementerian Kesehatan Republik Indonesia dan Direktur Utama Badan Penyelenggara Jaminan Sosial Kesehatan Nomor HK.01.08/ III/ 980/ 2017 Nomor 2 tahun 2017 tentang Petunjuk Teknis Pelaksananaan Pembayaran Kapitasi Pemenuhan Komitmen Pelayanan pada Fasilitas Kesehatan Tingkat Pertama.

Peraturan Menteri Kesehatan Republik Indonesia Nomor 71 Tahun 2013 Tentang Pelayanan Kesehatan Pada Jaminan Kesehatan Nasional.

Simatur Zulfa R, dkk. (2014). Panduan Resmi Memperoleh Jaminan Kesehatan dari BPJS. Jakarta: Visimedia

Stikes Hangtuah. (2018). Panduan Skripsi. Pekanbaru: Program Studi Ilmu Kesehatan Masyarakat.

Suprianto Arip. Evaluasi Pelaksanaan Jaminan Kesehatan Nasional. Journal of Government and Public Policy Vol.4 No.1. (2017). Magister Ilmu Pemerintahan Universitas Muhammadiyah Yogyakarta.

Tristanto Yudhapura. Kebijakan Sistem Rujukan Dalam Rangka Menyongsong Jaminan Kesehatan Nasional. Jakarta: RS Pendidikan BUKR Kementerian Kesehatan.

Umami Shafiatul L, dkk. Analisis

Pelaksanaan Rujukan Rawat Jalan

Tingkat Pertama Peserta BPJS

Kesehatan Di Puskesmas Vol 6 No.2

(2017). Fakultas Kedokteran

Universitas Diponegoro. 